\section{LA PUESTA EN ESCENA DE LA AUTENTICIDAD. ANDALUCÍA, UN SIGLO DE FASCINACIÓN, DE BASILIO MARTÍN PATINO, Y EL “MATERIALISMO HISTÓRICO" EN WALTER BENJAMIN}

\author{
STAGING AUTHENTICITY. \\ ANDALUCÍA, UN SIGLO DE \\ FASCINACIÓN, BY BASILIO \\ MARTIN PATINO, AND \\ "HISTORICAL MATERIALISM" IN \\ WALTER BENJAMIN
}

\author{
Óscar Cornago Bernal \\ (CSIC-Madrid) \\ ocornago@ile.csic.es
}

\begin{abstract}
This article explores the theatrical estrategies that documentary genre develops to create an effect of reality. For this aim it will be analyzed the Basilio Martín Patino's production for television Andalucia, a century of fascination, a serie of five documentaries filmed from 1992 to 1996 for the public channel Canal Sur Television. These films will be compared to previous work of Martin Patino and to other critics and directors' points of view regarding documentary genre and simulation of objetivity in visual media. As methodology it will be discus the concept of "materialist history" in Walter Benjamin.
\end{abstract}

KEY WORDS: Basilio Martin Patino; documentary; televisión; media studies; Walter Benjamin; materialist history.

\begin{abstract}
RESUMEN: Este artículo explora las estrategias teatrales desarrolladas por el género documental para crear un efecto de realidad. Con este objetivo se analizará la producción para televisión de Basilio Martín Patino Andalucía, un siglo de fascinación, una serie de cinco documentales filmados entre 1992 y 1996 para la cadena pública Canal Sur Televisión. Estas películas serán comparadas con trabajos anteriores de Martín Patino y con el punto de vista de críticos y directores en relación a las prácticas documentales y la creación de un efecto de objetividad en los medios audiovisuales. Como metodología se aplicará el concepto de "historia material" desarrollado por Walter Benjamin.
\end{abstract}

PALABRAS CLAVE: Basilio Martín Patino; documental; televisión; análisis de los medios; Walter Benjamin; materialismo histórico.

Este es un oficio apasionado, aparatoso, desproporcionado, engañoso. Hoy va de poetas como podría ir de deportes, del Papa o del homenaje a una folclórica. Excitante y efímero poder de ser creadores de espectáculos. Un circo que los mantiene a todos felices en la misma jaula de espejos deslumbrantes. Hermosa vanidad la de saberse fabricantes de escenarios con los que fascinar y amplificar los mitos, que es como amplificar la nada.

(Basilio Martín Patino, El jardín de los poetas, 1996, 00:09:01-00:09:36).

La exposición materialista de la historia lleva al pasado a colocar al presente en una situación crítica.

(Walter Benjamin, Libro de los pasajes, 473).

A comienzo de los años noventa Basilio Martín Patino acepta el encargo de la cadena Canal Sur Televisión para realizar cinco documentales de una hora de duración cada uno sobre Andalucía'. En 1996 estarán terminadas las que finalmente serán seis películas, porque una de ellas, la dedicada al flamenco, se desdoblará en dos entregas producidas por La Linterna Mágica, la productora del mismo director. Durante 1998 se emiten al ritmo de una por mes, seguidas de un debate con invitados más o menos relacionados con el tema de cada documental, en el siguiente orden: Ojos verdes, dedicado al mundo de la copla; Carmen y la libertad, sobre el mito de Carmen, la mujer obrera, seductora y revolucionaria; El grito del sur. Casas Viejas, documentación del levantamiento rural de 
signo anarquista de 1934 que acabó con una matanza a manos de la Guardia Civil; El jardín de los poetas, en forma de gala de televisión en homenaje a la Generación del 27, coincidiendo con el 50 aniversario de la muerte de Lorca; Desde lo más hondo I. Silverio y Desde lo más hondo II. EI museo japonés, ambas sobre el flamenco y la creación en Japón de un museo del cante hondo realizado con la más avanzada tecnología digital, y la última entrega, Paraísos, que recorre la historia de las comunidades libertarias en Andalucía.

Martín Patino sólo estará presente en uno de estos debates, el que siguió a Casas viejas. Apenas intervino para defender su lugar, no como historiador o experto en alguno de estos temas, como tantos de sus personajes inventados para estos documentales, sino como creador de espectáculos a través de las imágenes: "Naturalmente, me informo lo mejor que puedo, recojo todas las versiones posibles, pero después las mezclo, hago un 'puzzle' con los datos, los manipulo y se lo ofrezco al espectador para que colabore, creando él su propia película, como un ser mayor de edad" (Pérez Millán, 2002, 309), para terminar insistiendo, instado a tomar nuevamente la palabra al final del debate:

Ya dije antes que no soy catedrático de nada, sino un cómico que hace películas para entretenimiento colectivo. Reconozco que soy un falsario, que se inventa a otros falsarios para que hablen por mí... Todo es invención, y yo reivindico el derecho a hacer espectáculo, así como acepto que después me lo reprochen, o incluso me lo rechacen. Están en su derecho. Este juego es así (ibid.).

El objetivo del encargo, según representantes de la cadena pública de radio y televisión andaluza, era "la realización de un proyecto 'emblemático' sobre la historia y la realidad de Andalucía con el objetivo de hacer patrimonio audiovisual" (Martín Morán, 2005, 67). El director salmantino acepta el reto, aunque pide libertad para llevarlo a cabo. Si hay algo que quedaba descartado, revisando sus trabajos anteriores, era un tratamiento irreverente, irrisorio o burlesco de la realidad que tenía que ser filmada. La mirada de Martín Patino, desde esa distancia serena característica de su obra, pasa antes por la ironía que por la burla, pero siempre desde el respeto a la realidad humana que está mostrando. La ironía, como marca de una presencia solapada del autor dentro de su obra, fue ya una característica del realismo galdosiano en el siglo XIX. A finales del siglo XX Martín
Patino participa desde el medio audiovisual de ese mismo gusto por dejar ver -sólo para quien lo quiera ver- un guiño al espectador. Ese guiño se asoma por detrás de la aparente objetividad documental o realista, según se trate de un registro de no ficción o ficción que, como él mismo ha dicho en numerosas ocasiones, son parte del mismo juego. El director asume la reconstrucción de esa dimensión "emblemática" o mítica que tenía que tener el proyecto, incluso con un cierto distanciamiento respetuoso, que sólo en algunos casos, como en el documental sobre los poetas, se quiebra por la vía de una ironía que estalla en abierta comicidad; en este caso, sí se permite llegar a la caricatura del medio televisivo y la industria cultural, que no del mundo de los poetas y la poesía.

La estrategia para la reconstrucción "documental", en la que radica el ejercicio creativo del director y su equipo de colaboradores, pone al descubierto el discurso mítico de esas realidades andaluzas al mismo tiempo que los soportes actuales sobre los que se levantan esos mitos. Como explica el director: "La estética del verismo es algo que no me interesa si no es para desenmascarar dialécticamente la engañosa tapadera de la realidad que suele ofuscarnos" (Martín Patino y Useros, 2004). La pregunta que sigue sería: ¿cuál es la "engañosa tapadera de la realidad que suele ofuscarnos" cuando esta realidad es mostrada a través de la televisión?

No se trata de dar la vuelta a estos mitos, ni de destruirlos mostrando lo que tienen de lugares construidos - ¿y quizá por ello falsos?-, lo que hubiera supuesto un cierto maniqueísmo que Martín Patino siempre ha tratado de esquivar, sino de una postura de respeto que deja ver lo que estos mitos tienen de construcciones de verdad al tiempo que son cuestionados desde la mirada presente. Lo principal es que, a pesar de las apariencias, el juego fílmico no consiste en demostrar que hay unas verdades por encima de unos lugares construidos y falsos; no se trata de decir cuál es la verdad o la mentira, sino de hacer cine, de construir imágenes, que en el ámbito de la televisión se refieren a escenas que muestran y ocultan al mismo tiempo, conscientes de su condición de tales.

En este giro autorreflexivo, desarrollado no sólo a nivel temático, sino sobre todo en el plano formal, es en donde hay que buscar el espacio en el que se sitúa el director, un espacio intermedio, ambiguo, que no opera por afir- 
maciones o negaciones contundentes, sino más bien por cuestionamientos, elipsis y preguntas. Es en este espacio sutil, abierto por un uso de las imágenes y los escenarios que remiten a un afuera, a una realidad exterior y presente, en el que hay que rastrear lo que estos trabajos nos dicen finalmente acerca de "la historia y la realidad de Andalucia con el objetivo de hacer patrimonio audiovisual" (Martín Morán, 2005, 67).

Retomando la metodología que Walter Benjamin (2005, 459) expone al comienzo del Archivo $\mathrm{N}$ del Libro de los pasajes, dedicado a "Teoría del Conocimiento, Teoría del Progreso" -cuyos presupuestos para una historia materialista nos van a servir de guía en este ensayo-, Martín Patino no parece tampoco que tenga, como dice Benjamin, "nada que decir. Sólo que mostrar" (2005, 462). Se trata de adoptar el principio del montaje, no sólo como estrategia de relación entre las imágenes, sino también como forma de pensamiento crítico, de las imágenes y al mismo tiempo de la historia que encierran esas imágenes. La idea del montaje implica un "arte de la cita sin comillas" (Benjamin, 2005, 460), que Martín Patino ha potenciado desde el comienzo de su carrera a través de recursos ficcionales, construyendo pasajes con apariencia de citas, "falsas citas", podríamos decir, parafraseando la denominación de "falsos documentales" con los que la crítica cinematográfica ha clasificado este tipo de películas (Weinrichter, 2005; Nieto Ferrando, 2006 y Martín, 2008); una denominación que el director salmantino rechaza preguntándose si hay algún documental, es decir, alguna cita, siguiendo con el paralelismo, que no sea falsa. Yuxtapuestas unas a otras, estas citas de la realidad, transformadas en imágenes, como fragmentos construidos de la historia, cobran autonomía, no sólo histórica, sino también material, en tanto que escenas construidas: "No hurtaré nada valioso, ni me apropiaré de ninguna formulación profunda. Pero los harapos, los desechos, esos no los quiero inventariar, sino dejarles alcanzar su derecho de la única manera posible: empleándolos", dirá Benjamin $(2005,462)$.

Este planteamiento permite esquivar los peligros de lo que el filósofo alemán denomina una "forma burguesa de pensar" o "naturalismo histórico vulgar" (Benjamin, 2005, 463), que opera a través de los conceptos de "progreso" o "decadencia", conceptos que implican una continuidad entre pasado y presente. En su lugar, se propone la idea de "actualización", que funciona a partir del choque entre lo que ha sido y ya no es, el pasado, y lo que está siendo, el presente. Se trata así de atrapar "la construcción de la historia en cuanto tal. En estructura de comentario" (ibid.). Este tono de reflexión hace justicia también a la voz última que resuena tras la obra de Martín Patino, un comentario personal y distanciado, irónico, siempre ambiguo y hasta contradictorio, sobre la historia, de la historia política y social al mismo tiempo que de la historia de los medios, la historia del documental y las formas de grabación y retransmisión, un comentario actualizado cada vez desde su presente, que ha ido variando desde aquellos años sesenta cuando comenzó haciendo pequeños trabajos documentales, a veces con un aire costumbrista, a los que siguieron aquellas renombradas Nueve cartas a Berta. Desde aquella España inmersa en el Franquismo hasta estos años noventa de desbordado desarrollo económico, en los que transcurre Andalucía, ha cambiado mucho, no sólo la historia, sino también los modos de retransmitirla.

Estas películas son, por tanto, un patrimonio audiovisual, pero no sólo por lo que tienen de actualización-mejor que recuperación- de un pasado y unos valores considerados esenciales en la cultura andaluza, sino sobre todo, y en primer lugar, por lo que nos dicen del presente, también histórico, el presente de la Andalucía en la que se filman y se proyectan; una España consolidada políticamente a través de una economía neoliberal, impulsada por un vertiginoso proceso de modernización. Los acontecimientos pasados, lo que ya ha sido, la realidad histórica del flamenco y la copla, de las revoluciones agrarias y las comunidades libertarias, de aquel mítico esplendor poético, parecen tan pasados, tan encerrados en otro tiempo, que su mera actualización, desde este presente aparentemente tan nuevo, el tiempo actual de lo que está siendo, da lugar a ese choque dialéctico que Walter Benjamin decía que debía producirse en el diálogo, con un tiempo anterior, que quisiera llegar a una verdad sobre su presente. Por esto afirma Benjamin que "mientras que la relación del presente con el pasado es puramente temporal, continua, la de lo que ha sido con el ahora es dialéctica: no es un discurrir, sino una imagen, en discontinuidad" $(2005,464)$, para continuar aplicando este enfoque dialéctico a las imágenes, que en la filosofía de Benjamin ocupan el centro de su teoría del conocimiento: "Sólo las imágenes dialécticas son auténticas imágenes (esto es, no arcaicas), y el lugar donde se las encuentra es el lenguaje del despertar" (ibid.).

ARBOR Vol. 187748 marzo-abril [2011] 223-236 ISSN: 0210-1963

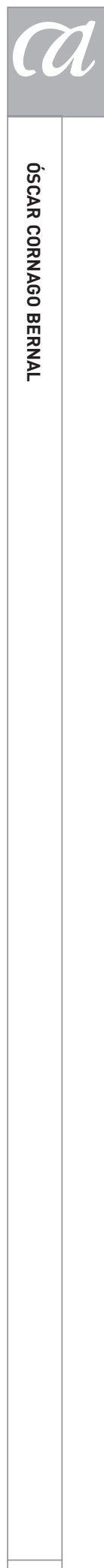

225 
Este despertar, siguiendo al autor de El libro de los pasajes, opera con las mismas herramientas del mito y la ensoñación, del encantamiento y la fascinación, ideas todas ellas fundacionales del pensamiento audiovisual de Martín Patino que, por encima de cualquier otra función, siempre defendió la condición primera del cine como fuente de fascinación, a mitad de camino entre el juego, la ensoñación y el misterio, términos clave también en la filosofía de Benjamin. Así, en la introducción al libro Artilugios para fascinar, dedicado a la colección del director de aparatos e ingenios técnicos que desde el siglo XVII se hicieron para poner las imágenes en movimiento, decía: "Su finalidad no es narrar u objetivar conductas relacionadas con verdades ni mentiras, sino fascinar. Ensoñaciones caleidoscópicas y musicales, abstracciones fetichistas, míticas, telúricas, eróticas, ajenas a toda reflexión ética o intelectual" (Frutos Esteban, 1999, 15).

Sobre un sistema de contrastes y tensiones entre pasado y presente se construyen estos documentales, contrastes entre imágenes de un pasado lejano, por un lado, que llegan al presente cargadas de misterio, de capacidad de fascinación, e imágenes del tiempo más inmediato, por otro, de lo que está siendo actualmente, a finales del siglo XX, la Andalucía de hoy, moderna, europea y desarrollada, sin dejar de estar cubierta por mitos. Esa tensión detenida atrapada en una imagen, pensada más bien como una escena en la que se ordenan una serie de elementos dispares, produce lo que Benjamin llama la "imagen dialéctica", comparable a lo que el siglo XVII identificó como "alegorías". En cierto modo, estos documentales también pueden ser vistos como alegorías, imágenes detenidas de la sociedad de esa Andalucía de hoy, tan volcada hacia el futuro como cargada de historia. Llegar a atrapar el tiempo histórico en una suerte de imagen detenida, vista como algo ya concluido, es una condición necesaria para poder entender cualquier época. Este reto se hace más difícil cuando se trata del tiempo actual, aunque cualquier tiempo, siguiendo a Benjamin, remite al momento presente desde el que se mira.

El objetivo de este artículo es estudiar en qué medida estas constantes de la obra de Martín Patino, como su atención por la historia, su mirada al pasado, su sentido de presente, su relación conflictiva con el registro documental y la reflexión paralela sobre los medios, se actualiza en este nuevo proyecto para televisión que es Andalucía, un siglo de fascinación. Para ello vamos a continuar con una línea de estudios ya iniciada (Cornago, 2005) acerca de los medios desde una doble perspectiva, por un lado, el análisis comparado de éstos a partir de sus características materiales (Dubois, 2003), y, por otro, de las propuestas de Walter Benjamin (2005) para una historiografía material. Ambos ejes, el análisis formal de los medios y la discusión del materialismo histórico en torno al concepto de "imagen dialéctica", se cruzan una vez más a lo largo de la obra de Martín Patino, en este capítulo audiovisual protagonizado por el desarrollo de las televisiones privadas y públicas y la tecnología digital en los años noventa.

La relación del director de La seducción del caos con el medio televisivo viene en realidad de atrás, de finales de los años setenta cuando comienza a explorar las posibilidades del vídeo al tiempo que pone en marcha una iniciativa de televisión local (Bellido López, 1996). A la altura de los noventa este camino de experimentación adquiere desarrollos específicos, producto también de un contexto histórico distinto, que le permiten confrontar los mitos de la cultura andaluza con la inmediatez material y comunicativa de la televisión, para conseguir levantar un interrogante no sólo sobre la historia social de España, sino en paralelo sobre la propia historia de los medios que la han acompañado. Este proceso, en ambos casos, resulta de un acercamiento material que pasa, en primer lugar, por un tratamiento reflexivo de las estrategias de comunicación que está empleando, ligadas a la televisión.

Es significativo que entre todos los trabajos de la serie haya sido el más cinematográfico, Casas viejas, el que le valió el elogio de la crítica por encima de los demás, que inicialmente podemos valorar, con Pérez Millán (2002), como muy desiguales. Efectivamente, la recreación ficcional en Casas viejas de dos documentales, uno dentro de la escuela británica de John Grierson y otro, incluido en su totalidad, dentro de la escuela soviética, permite ver esta película como una culminación del trabajo de Martín Patino sobre el documental de tema histórico desde los años setenta. Sin embargo, Casas viejas es el que menos se adhiere al juego televisivo y la recreación de escenarios característicos de este medio, como el plató convertido en escenario de debate o entrevista. La obra de Martín Patino, tanto en su producción de ficción como en trabajos documentales, ha ido creciendo sobre esta tensión entre la historia y el presente, entre la mirada al pasado y el momento actual desde el que se mira, entre el relato filmado y el contexto 
de la filmación. Esta tensión adquiere a través del juego de la comunicación televisiva una nueva formulación con una apariencia quizá menos artística, pero con una enorme eficacia en la apertura de un espacio intermedio que interesa de forma especial al cine de Martín Patino entre la imagen y el espectador, convertidos por el dispositivo de la televisión, en el que habla y el que escucha, o en un marco más amplio, entre el director, de la película, de la cadena de televisión o del programa, y la sociedad. Entre estas dos instancias Martín Patino abre un espacio vivo y contrastado, un espacio de juego e interrogación, a veces irónico y hasta cómico, y siempre cargado de una voluntad crítica que sitúa al espectador en un lugar activo desde el que tiene que decidir acerca de lo que está viendo, ¿realidad o invención?, ¿juego o historia?, ¿verdad o mito? Un juego mediático acerca de la verdad de las imágenes "históricas", convertidas por este sistema de contrastes en "imágenes dialécticas", imágenes que hablan no sólo de la historia de esas mismas imágenes y los aparatos que hicieron posible su grabación, sobre lo que el director no deja de reflexionar, sino también de la historia que queda oculta alrededor de las imágenes, lo que queda fuera, el espacio entre medias, entre el que se coloca frente a la cámara y quien está detrás de ella, o entre el que mira la imagen y la propia imagen convertida en un jeroglífico para descifrar el presente de quien la observa. La imagen, cuya condición escénica es reforzada por el dispositivo televisivo, se presenta como una clave que oculta celosamente el secreto de una historia.

La mirada del alegorista, en términos benjaminianos, se produce, como la de Martín Patino, desde una distancia que deja ver al mismo tiempo la fascinación que le produce esa imagen y el deseo de comprender el secreto que oculta, juego y misterio. Lo más familiar al espectador, como esas escenas estereotipadas que Martín Patino vuelca a lo largo de estos documentales, queda rodeado por un velo que produce extrañamiento y fascinación a la vez. El espectador se reconoce en lo que mira, identifica con facilidad esos locutores de televisión o radio, las escenas de tertulia y debate, los expertos dando su opinión sobre cualquier cosa o las personas anónimas expresando con vehemencia su adhesión o rechazo acerca del tema tratado; pero al mismo tiempo que los reconoce, descubre todo ese paisaje de declaraciones e imágenes construidas revestido de un halo escénico que le devuelve la escena como algo distante, que le llama la atención a la vez que le interroga acerca de ese montaje al que está asistiendo, el montaje de la historia reforzado a través de las imágenes, la historia convertida no ya en ficción cinematográfica, sino en plató de televisión.

Lo importante no es, sin embargo, la resolución del juego, llegar a saber cuál es la verdad y cuál es la mentira, con el fin de establecer un límite cierto, sino el espacio de juego que se despliega y la puesta en marcha por parte del espectador de una recepción activa, un momento en el que se juega, ya del lado de quien mira, el sentido final de las imágenes. Esta dinámica está en contra, pues, tanto de los discursos de autoridad que tienen como paradigma no ya el registro documental, sino el medio mucho más difundido de la televisión. Esto explica que desde los años noventa la televisión confluyera con el modo documental como estrategia de creación de una verdad objetiva, mientras que el cine de creación, cargado con una voluntad documental cada vez más transparente, se aliaba con la ficción para poner en duda este discurso de autoridad, un cruce que, como en el caso de Martín Patino, comienza a producirse en los años sesenta y setenta.

La escena de Hans, en Madrid, examinando con lupa las fotografías de la Guerra Civil o las tomas de los documentalistas que vinieron a filmar la contienda, refleja cómo el propio Martín Patino se sitúa frente a la imagen, con la distancia del que trata de descifrar un secreto, de ver más allá de lo que la imagen parece mostrar. En ese esfuerzo radica también su compromiso con el presente, desde el que se enfrenta a esas imágenes del pasado o a la construcción de otras nuevas que a menudo se hacen pasar por tales. En un momento de la película se afirma que aquellos directores eligieron estar en su tiempo, es decir, en su presente. Ése es el otro reto del director como creador de imágenes, captar las imágenes que corresponden a su época, y éste es también el reto que Benjamin (2005, 476) señala para el historiador materialista, para el cual todo pasado, por remoto que pueda parecer, es siempre la antehistoria del presente.

A diferencia del cine, recubierto pronto con una aureola artística que lo llevó del nacimiento a una rápida conversión en clásico y en lenguaje artístico por antonomasia de la modernidad, a la vuelta de sólo unas décadas, la televisión no ha perdido su carácter controvertido. Conoció una época de difusión, como otros medios públicos de retrans- 
misión, ligada a un cierto discurso estatal en relación con la democracia convertida en utopía política. Pero pronto se descubre su potencial como estrategia comercial y su capacidad de influir en la opinión pública, no siempre con el ánimo de incentivar ese pensamiento plural que debía alentar la cultura de la democracia. Pasadas las primeras décadas de televisión pública durante los años sesenta y setenta aparecen las cadenas privadas para terminar de mostrar las "virtudes" del nuevo medio durante los años noventa, al tiempo que se consolida una economía neoliberal que termina de acabar con el modelo de televisión pública que habia habido hasta entonces. Paradójicamente, la televisión adquiere protagonismo a la vez que el discurso de condena de este medio se convierte en lugar común. Benjamin afirma $(2005,476)$ que la impresión de transparencia social es proporcional al éxito con el que se impone una nueva tecnología. Efectivamente, la televisión como medio de comunicación de masas, renovado con la tecnología digital que ha permitido perfeccionar su apariencia participativa, acentuando esa impresión de transparencia, no ha perdido esa rara invisibilidad que en cada época han ostentado los medios capaces de crear un mayor efecto de realidad.

Puede sorprender que un director de reputada trayectoria en el ámbito cultural se dedique a hacer televisión. Sin embargo, para quien conoce el trabajo de Martín Patino no sólo no sorprende esta evolución, sino que parece que alcanza una llamativa coherencia dentro de una trayectoria que no ha dejado de pensarse desde las posibilidades técnicas que fueron brindando los nuevos tiempos. Esquivando posturas maniqueas acerca de la bondad o la miseria de cada nuevo dispositivo técnico de producción de imágenes, Martín Patino descubrió en la acelerada evolución mediática vivida desde los años setenta la oportunidad de entender y trabajar en el campo de la producción y difusión de imágenes con una renovada libertad, una libertad que prefirió buscar en los resquicios abiertos por las nuevas tecnologías antes que seguir insistiendo por la vía de los lenguajes ya consolidados, como el formato tradicional cinematográfico, en gran parte absorbido por el mercado de consumo. Desde una postura de rechazo a la mercantilización del cine, Martín Patino encontró primero en el vídeo, la televisión y, más tarde, en la tecnología digital nuevas posibilidades para trabajar con las imágenes, sin renunciar por ello, sino al contrario, a algunas de las constantes que le han acompañado durante su carrera, como la defensa de la dimensión lúdica y espectacular de la imagen; su capacidad de seducción y a la vez, y quizá de manera implícita, el diálogo con su presente, el presente de la filmación y retransmisión de las imágenes, a través de la revisión de la historia.

El carácter autorreflexivo de su trabajo, la conciencia de saberse en primer lugar como un creador de imágenes que, más allá de lo que representan, constituyen un juego óptico, bastaría para explicar esa especie de teatralidad que invade su universo visual, una teatralidad callada e introspectiva en unos casos, especialmente en sus películas de ficción, y explícita, irónica y hasta cómica en otros, como en estos documentales para televisión ya en los años noventa. La necesidad de llevar a cabo una reflexión acerca de la condición de las imágenes, del hecho de la filmación y de la presencia del espectador al que va dirigido todo ello, lleva a Martín Patino, como a otros creadores a partir de los años sesenta, a hacer sentir, cuando no dejar ver abiertamente, la puesta en escena que rodea a la imagen, los condicionantes materiales que acompañan la producción de imágenes. Una postura autorreflexiva que se abre ya con aquellos primeros estudios sobre el montaje cinematográfico, del que se ocupa al comienzo de los años sesenta, como más tarde, a través de su trabajo en el medio publicitario (Bellido López, 1996).

Desde los años setenta, el desarrollo de nuevas tecnologías, que habian comenzado con el aligeramiento de los equipos de grabación, a lo que siguió el vídeo y luego la tecnología digital, permitió una mayor movilidad de la cámara, que hizo posible un nuevo tipo de relación con la imagen y el trabajo de filmación. El vídeo, como ha estudiado Dubois (2001), se convierte en un instrumento de reflexión acerca del propio cine. Numerosos creadores desde los años setenta lo utilizan dentro de sus películas para llevar a cabo este giro autorreflexivo, dejando ver, por contraste, la diferencia entre la imagen del vídeo, más inmediata, cercana y material, y la imagen del cine, identificada con el montaje de planos y la profundidad de campo. Frente a esto, el vídeo despliega un espacio entendido como superficie de acción que remite al mismo escenario donde tiene lugar esa acción (de filmar). El vídeo, como la otra cara de la televisión, resalta la relación entre la cámara y lo que está siendo filmado, de modo que la presencia de la cámara se hace más fuerte $y$, por ende, también la de aquel que se muestra frente a ella. Esto abre un eje transversal de inte- 
racción cámara-actor, diferente al eje horizontal donde se ordenaba el relato cinematográfico clásico, sostenido por la transparencia de las estrategias de grabación y montaje. La televisión puede ser considerada una suerte de teatro electrónico (Cornago, 2005, 271ss.), donde la impresión de cercanía e interacción con el público es simulada desde los propios dispositivos de enunciación.

La televisión hace posible trabajar esa sensación de presente con nuevas estrategias que enfatizan una relación cara a cara, en el aquí y ahora (escénicos) de la retransmisión. La impresión de presente es fundamental para abrir una brecha en el lugar donde acaba el pasado que se está tratando de actualizar a través de las imágenes. La ruptura de la linealidad de la historia puede ser elaborada, como en el caso de Martín Patino en estos documentales, desde las estrategias de comunicación características de la televisión. El mismo poder de fascinación que ejerce este medio por su impresión de proximidad, de "verdad", puede ser utilizado para despertar de ese efecto hipnótico que tiene el propio medio, sacando a la luz, en el instante de la recepción, el momento presente que marca la línea de discontinuidad con el pasado, un momento de ruptura desde el que pensar el origen de la historia en cada momento, no el origen en sentido temporal, sino el sustrato originario que subyace a cada presente, 0 en palabras de Benjamin: "el presente determina en el objeto del pasado dónde se separan su ante- y posthistoria, para captar su núcleo" $(2005,478)$.

No es casualidad que diversos teóricos y directores hayan puesto de manifiesto esta dimensión escénica abierta para la imagen con el vídeo, y cuyo paradigma en la comunicación de masas es la televisión y, más tarde, las comunicaciones por Internet. A lo largo de los años setenta, a medida que se difunde el uso del vídeo, este aparato brinda la posibilidad de romper la imagen cinematográfica atravesándola con una trayectoria espaciotemporal distinta. Esto se utilizó tanto para desarrollar un pensamiento explícito acerca del cine, como para dar la vuelta a las estrategias televisivas con el objeto de articular otras posibilidades distintas de las que se han desarrollado al servicio de la comunicación de masas y la economía de consumo. Con razón se preguntará el realizador de El jardín de los poetas si "no es un modo de complicidad el aceptar que todo lo que toca a la televisión tenga que convertirse en barracón circense que tiene que gustar a millones de espectadores para poder amortizarlo en cuanto a publicidad" (00:23:1700:23:26). Contra esta forma de complicidad se alza el vídeo como un modo de colocar el mismo medio de la televisión en una dirección distinta.

El concepto de "cinescenia", acuñado por Vilém Flusser, un teórico que desde los años setenta se dedicó a pensar las relaciones entre medios, sociedad e ideología, combina esta doble dimensión de lo cinematográfico con lo escénico. "En la cinta de vídeo -explica Flusser-, reproducción y escena se interfieren. Se trata también de una ilusión óptica; pero de una ilusión con otras posibilidades de manipulación, que están más cerca del umbral de la realidad de la escena" (Russo, 2005, 141). Cinescenia hace alusión a un tipo de imagen que se construye como interrogante acerca de su modo de producción y transmisión, una imagen que nos habla no sólo de lo que muestra, sino también de lo que no se ve, de sus relaciones con la cámara y quien la manipula, de sus relaciones con el objeto de filmación $y$, finalmente, de sus relaciones con quien la mira. Cinescenia es, por tanto, un tipo de imagen que invita a pensar ese complejo espacio de la puesta en escena de la propia imagen viajando a través del tiempo.

Compartiendo este mismo enfoque, el director y crítico de cine Jean-Louis Comolli, que ha desarrollado la mayor parte de su producción en el campo documental y que ha trabajado también para televisión, comparable en este sentido con la trayectoria de Martín Patino, se refiere a la potencialidad crítica de la dimensión escénica de ciertas tecnologías de la imagen. El término "puesta en escena", que en el medio teatral ha sido tradicionalmente reducido al plano de la representación de un texto, es rescatado, no desde esta óptica representacional, sino por lo que implica de "puesta en relación" con el otro, con el que también está en escena, aunque no aparezca directamente en la representación. Esta autenticidad de lo relacional es lo que se reivindica desde los años setenta como un modo de romper el universo de las imágenes con una mirada desde afuera:

Un postulado: actualmente la puesta en escena lleva realidad en sus redes.

Una respuesta: la puesta en escena sirve para plantear la cuestión del espectador en un sistema de representaciones mediáticas (televisión, noticias, publicidad) que no solamente no la plantea, sino que teme plantear y aún más, hace todo lo posible para rechazarla.

ARBOR Vol. 187748 marzo-abril [2011] 223-236 ISSN: 0210-1963

(n)


La puesta en escena representa la cuestión del lugar del espectador, de la definición de espectador, de la suposición de un espectador como sujeto total, ser que desea, ser pensante, ser social. No quien observa qué (consumo, espectáculo) sino quien mira a quién -relación y toma del otro más o menos aseguradas-, distancia del otro y de sí más o menos grande, reconocimiento, miedo, cambio (Comolli, 2008, 103).

De igual modo, el género documental, convertido en uno de los formatos estrella de la televisión desde los años noventa en provecho de los índices de audiencia, ha sido reconsiderado desde esta dimensión relacional abierta desde los setenta. El director y teórico del cine Paul Breschand eleva a la categoría de "Ley Breschand" algo que el mismo Martín Patino no tendría problemas en suscribir, como que "en cuanto una imagen viene con la etiqueta de objetividad (por su dispositivo de enunciación, por su comentario), podemos estar seguros de que está siendo empleada como cebo" (Brechand, 2004, 26), para definir a continuación el cine documental, del que él mismo también se ha ocupado, como la "huella de un encuentro" (Breschand, 2004, 31), un encuentro precipitado por el propio rodaje.

En el caso de Martín Patino, el pensamiento de la imagen, la manera de entender el trabajo como director y la relación propuesta al público, reflejo a su vez de la relación del sujeto con la historia, ha ido cambiando conforme esa misma historia, que es la historia política de España, pero también la historia de los medios, se ha ido transformando y los tipos de puesta en escena fueron variando. Desde los últimos años del Franquismo, que le llevaron a un profundo trabajo de revisión de lo que había supuesto ese período, hasta los años noventa, que trajeron esa España tan renovada, de la que la serie de Andalucía supone sin presentarse como tal una suerte de radiografía, la mirada de Martín Patino ha experimentado nuevas formas de jugar con las imágenes. Entre medias, una Transición política que se apresuraba a dejar atrás el pasado al tiempo que se descubrían nuevos horizontes. Esto es lo que se encuentra Hans en Madrid (1987), al que una cadena alemana encarga un documental sobre la Guerra Civil con motivo del 50 aniversario. Sin embargo, lo que Hans termina mostrando, volviendo la mirada a su presente, sin por ello dejar de recuperar el pasado, es esa España que deseaba una nueva libertad.
Corrían los años ochenta, y verdades y mentiras, ficciones y realidades se superponian a un ritmo que sólo los medios de comunicación hacen posible. Esto no era una sorpresa para un director que cambia con comodidad del registro ficcional al documental, consciente de que este último no es más que otro tipo de juego, sólo que además se finge realidad. Es entonces cuando Martín Patino pone en marcha un proyecto de televisión comunitaria y experimenta con un periodismo de carácter audiovisual que editó en formato de vídeo. $Y$ ya para finales de esta década empezó a trabajar en un proyecto para televisión, Apócrifos -cuyo título es ya suficientemente explícito-; este proyecto será luego convertido en espina dorsal de la película también para televisión $L a$ seducción del caos. En el trabajo de Martín Patino es habitual el desarrollo, reutilización y reconversión de unos proyectos en otros, así como la existencia de numerosos proyectos inconclusos, que Bellido López (1996) cifra en una treintena. Esto responde a una idea recurrente en el director salmantino de justificar los proyectos no en función de los resultados finales, sino de la necesidad de llevar a cabo esa empresa y el proceso puesto en marcha por ésta, sin que en todos los casos tenga que conducir a una obra acabada. En paralelo con algunas prácticas habituales en las artes plásticas, un campo con el que la obra de Martín Patino también dialoga, materiales que fueron concebidos para trabajos que no llegaron a hacerse, se retoman en obras posteriores. Andalucia, un siglo de fascinación puede entenderse como un nuevo desarrollo, desde un lugar histórico y formalmente más inmediato, de aquellas pequeñas emisiones en torno a las mentiras, imposturas y simulaciones sobre las que se construye la historia de las ciencias, las artes, la religión o la política, que eran los temas de Apócrifos, recuperados en la serie documental Las galas del emperador, cuyos capítulos se van sucediendo a lo largo de La seducción del caos. Esta serie quedó inacabada y el capítulo que falta podría haber estado dedicado a las imposturas de los propios medios, que es el objeto de la película final, como si ésta en sí misma fuera ese capítulo de apertura o cierre que no llegó a realizarse. Esta suerte de continuidad explica que cuando Martín Patino recibe el encargo para la serie Andalucía, deje aplazada una película de ficción que será terminada una década más tarde, Octavia, para dedicarse a esta nueva aventura audiovisual, continuación de lo que venía realizando hasta el momento. 
Andalucía, para cuyo título se retoma esa figura recurrente en la obra de Martín Patino que es la idea de seducción, empleada ya en el título de su obra anterior, le permitirá dar un nuevo giro a la reflexión sobre las verdades y las mentiras de la historia, transformadas en juegos de imágenes, el lugar de lo auténtico y lo falso, y las políticas de la objetividad sobre las que se legitiman los discursos identitarios. Si en La seducción del caos asistimos a un desarrollo explicativo de los entresijos de los medios, ilustrado paralelamente por una trama detectivesca acerca del asesinato de la mujer de un conocido intelectual mediático y la pareja de ésta, un estrecho amigo del intelectual, de clase alta y afinidades con el pensamiento de izquierdas, en Andalucía se pasará a una puesta en juego más directa de estos planteamientos mediáticos y culturales, aplicados a tramas aparentemente no ficcionales, como los mitos en torno al flamenco, la poesía o el pasado social de Andalucía. En el fondo, como explica el director a raíz de la presentación de la serie el 6 de noviembre de 1997, no se trata sino de un juego más construido sobre imágenes:

Les propongo que juguemos juntos, que participen lúdicamente... y esto es una ficción, aunque en el fondo, por la verosimilitud que yo intento darle, parece realidad. Es una ficción y la asumo, a veces disparatada, a veces, a lo mejor, excesivamente realista como la vida misma, como la propia Andalucía... Disculpen mi atrevimiento al dar esta visión personal, la mía (puede haber tantas otras)... que ustedes complementarán y que someto a su crítica (Martín Morán, 2005, 67).

El tratamiento de cada uno de estos temas se apoya, por un lado, en una documentación histórica, expuesta con pretendida objetividad, y, por otro lado, en el despliegue de complejos dispositivos de enunciación, articulados en torno a una trama a menudo sólo aparentemente real. Este dispositivo de enunciación puede ser de signo muy distinto, pero en todos los casos se deja ver su carácter material, abiertamente expuesto, al igual que el tema objeto de documentación, de modo que el público se sienta invitado a tomar una postura acerca de lo que está viendo, mostrado siempre en forma de conflicto, no sólo temático sino material. Entre el tema de estudio y el dispositivo puesto en imagen se levanta un sistema de tensiones que articula cada película. El carácter material de estos dispositivos hace que este sistema no se desarrolle únicamente en el plano de los contenidos, como la actualidad del flamenco, de la copla, de la poesía andaluza y del mito de Carmen, o la relevancia hoy en día de las luchas políticas de otro tiempo. Cada uno de estos campos queda atravesado por estos dispositivos materiales que obliga a discutirlos también desde el continente utilizado para su (re)presentación. Frente a ese "portentoso mirar hipnótico sin ver, oír sin escuchar", como se define en El jardín de los poetas (01:07:12-01:07:17) la comunicación televisiva, Martín Patino trata de dialogar con un espectador al que se invita a decidir acerca de lo que está viendo, en busca de esa "dialéctica del diálogo cómplice con el espectador, abierto y crítico" (Martín Patino, 1987).

Casas viejas, desde ese tono más cinematográfico, es la única donde la veracidad de los materiales de archivo empleados puede quedar en duda hasta los títulos de crédito finales, que desvelan el nombre de los actores que han participado en esos supuestos documentales de los años treinta, pero incluso hasta ese momento el acontecimiento discutido se deja ver desde enfoques y estilos diversos, que al final se muestran como construidos para esa película. En cierto modo, esta obra, como otras anteriores de Martín Patino, así, por ejemplo, Madrid, lleva implícito un homenaje a aquellos documentalistas que vinieron a España para grabar estas imágenes, con la diferencia de que en Madrid se trataba en su mayor parte de imágenes realmente tomadas de estos directores y en Casas Viejas fueron fabricadas para dar esa impresión de autenticidad cinematográfica.

El debate sobre la Historia y sus modos de transmisión, fácilmente manipulables, quedaba abierto para ser continuado, tras la proyección, por otros "expertos", que parecen continuar el papel -y el juego- de los que salían en la película, o por los propios espectadores en sus casas. Como si de un juego de cajas chinas se tratara, estos posibles debates están ya incluidos de forma incipiente en las obras. Podríamos imaginar una versión ampliada de cada uno de estos documentales en los que los invitados al plató tras la proyección de la película y, más allá, los propios espectadores, fueran actores de la propia película.

En el resto de las entregas el contraste entre lo auténtico y lo falso se va a acentuar desde el comienzo, incluso en términos exagerados que no temen rozar lo cómico. Silverio se abre con un fabuloso juego de imágenes aéreas donde se pasa de la Sevilla de las tascas, el flamenco y 
los toros a las concurridas calles del Tokyo actual. El contraste no puede ser más extremo, así como la peregrina invención propuesta desde la película: la investigación de una multinacional japonesa de aparatos de audio para reproducir a partir de una lámina de cobre aparecida en una subasta la voz de Silverio Franconetti, un cantaor del siglo XIX, considerado uno de los mejores del flamenco y de cuya voz no se tenía registro. Esta quijotesca historia se lleva al extremo con el museo virtual del cante jondo que el director de esta empresa, Eikichi, lleva adelante y al que se hace una visita en la segunda parte de la película, El museo japonés. Cantaores de flamenco, con rostros y voces auténticas, contrastan con el espacio infinito de la pantalla digital, por la que el usuario se mueve libremente. Algo tan local como el flamenco queda enfrentado a lo más deslocalizado, al no espacio de la imagen infográfica, producida por un programa de ordenador que el visitante puede manipular, como si éste fuera, finalmente, el dueño de estas representaciones (de la historia) del flamenco.

La discusión queda nuevamente abierta. A lo largo de un acalorado intercambio de opiniones entre artistas y flamencólogos, puestos en escena a través de debates televisivos, entrevistas, tertulias en cafés y charlas entre amigos, se va desarrollando la película. De fondo, la figura serena y emotiva de Eikichi, que trató de reproducir los misterios del alma andaluza con un sintetizador de voz. La defensa de las esencias identitarias, del alma de los pueblos, frente a las revoluciones técnicas, del misticismo frente a las leyes del mercado, la verdad del flamenco frente a la mentira de las reproducciones, sonoras o visuales, aunque se pretendan documentales, descubre un amplio espacio de discusión que va más allá de la verdad del flamenco para entrar en el terreno de la función de los medios, la sociedad de consumo y la formas de construir la historia. En algún momento de la película la cámara se detiene en estos primitivos aparatitos para reproducir la voz humana, máquinas parlantes expuestas con el mismo encanto que Martín Patino descubrió en esos otros aparatos ópticos, hermanos gemelos de éstos, con los que las imágenes dieron sus primeros pasos, ingenios producidos en laboratorios de algún científico visionario. En contraste con la rotundidad con la que se expresan algunos invitados a estos debates televisivos o personajes entrevistados en escenarios más populares -"se es místico porque se nace místico en esta tierra mística [...] Yo soy andaluz nato y neto, además por los cuatro costados" (00:15:10,
00:15:35), y más adelante: "El duende es una cosa nuestra, no nos lo pueden quitar. Hay que llevarlo en la sangre. No se puede aprender. [...] Es una cosa innata, de los andaluces, de los españoles, nuestra" (00:26:23, 00:26:48)-, la película se cierra con imágenes del industrial japonés cuidando sus bonsáis en su casa de Tokyo con su mujer y dos niñas jugando alrededor, antes de rememorar con contenida emoción aquellas lejanas noches por las tascas de Sevilla en las que se enamoró del misterio del cante. Un primer plano de su imagen congelada, tras estas escenas intimas de su vida familiar, cierra la película. ¿Dónde queda lo auténtico y dónde queda lo falso?

Otro ejemplo en el que la confrontación entre idealismo y materialismo se lleva al extremo es en Paraísos, un término también recurrente en la obra de Martín Patino. La nostalgia por un paraiso perdido recorre buena parte de sus películas de ficción y de manera explícita el largometraje Paraísos perdidos, la primera película de ficción que hizo después de la Transición. Esta nostalgia, habitada por un ideario social que en otro momento se creyó posible realizar, es la que impregna las utopías socialistas de las que se ocupa Paraisos, la búsqueda de otras formas de convivencia, de otras formas de vivir en armonía con la naturaleza y en libertad. Lo que en otro momento fueron utopias consideradas políticas hoy se revela como un sueño de burgueses que trataron de vivir al margen de la sociedad de su tiempo. ¿ldealismo revolucionario o egoísmo de clase? "Quizá la utopía -dice una de las protagonistas de estas aventuras libertarias, hoy convertida en gerente de un lujoso gimnasio en la costa andaluza- no sea nada más que esto, disfrutar de este clima maravilloso, de este paisaje sereno, de estos productos de la tierra. $Y$ desde luego para mí lo más importante: poder educar tranquilamente a mi hijo" (00:07:51-00:08:13).

Lo que en otro momento fueron idearios para mejorar las condiciones de vida de los trabajadores se convierten hoy en planes urbanisticos que se entrecruzan con el clima de especulación inmobiliaria caracteristico de la España de los noventa. Junto a la atractiva propietaria del gimnasio, van desfilando un profesor de sociología norteamericano, un viejo anarquista retirado en los parajes idílicos de la sierra gaditana, una mujer india, participante en otro de estos proyectos comunitarios, impulsado ya por una $\mathrm{ONG}$ a nivel mundial, y un arquitecto que coordina estas III Jornadas de Arquitectura y Ordenación Urbana que hacen de marco 
general de la película. Cada jornada está dedicada a una de estas experiencias de vida en común, el Falansterio, el Humanisferio, el Monasterio del Cuervo, donde se trató de reconstruir un falansterio tras la muerte de Franco, con ayuda de la Fundación Marshall, impulsada por una familia de capitalistas judíos, la Comunidad Libre de Ronda y Our Ville, en la India. "No nos interesa una confrontación con la ideología dominante. [...] La verdad es que la cosa ideológica no es nuestro fuerte. A nosotros nos preocupa mucho más la cuestión técnica, la tecnología" (01:13:41, 01:14:15), dice el arquitecto que dirige el proyecto urbanístico de Ronda mientras revisan el estado de las obras en un privilegiado asentamiento natural, un proyecto en el que no faltará televisión y conexiones por Internet para estar "democráticamente informados".

Al tiempo que se discute la confrontación entre la dimensión utópica de estos proyectos históricos y el pragmatismo al que se ha llegado, se suceden las imágenes y escenas estereotipadas tanto de esa Andalucía mítica como de la Andalucía actual, con los códigos teatrales característicos de esas jornadas internacionales en las que participan los protagonistas. Las escenas de felicidad de este grupo de amigos en el que se han convertido estos luchadores de otro tiempo están construidas a través de lugares comunes que las hacen fácilmente reconocibles para el espectador de televisión. Como si fueran personajes de otra época, nuestro propio presente cerrado sobre sí mismo, llegan hasta la imagen de la televisión recubiertos de un cierto halo onírico, acentuado por la música idílica y esos paisajes de ensueño que acompañan toda la serie, con ese brillo "imposible de eliminar en las imágenes producidas por el inconsciente colectivo" dirá Benjamin $(2005,47)$. Sonrisas detenidas en el tiempo, abrazos entre padres e hijos, palmaditas en la espalda entre viejos camaradas de luchas perdidas, y todo ello mirando a la cámara de frente, para que sean correctamente filmados para la posteridad. La conciencia de estar actuando frente a la cámara o frente a la historia está presente, la conciencia de ser figurantes dentro de un escenario convertido en alegoría donde se cifra el mensaje oculto de una época.

Mientras que Carmen y la libertad opone el mito de la mujer revolucionaria al mundo de los grandes espectáculos teatrales dirigidos por afamados directores internacionales y el paisaje de la cultura como aparatoso espectáculo de sí misma, El jardín de los poetas enfrentará el fenómeno de la poesía y más concretamente de la Generación del 27 con el medio televisivo; lo más etéreo con lo más material, cara a cara. Si en la primera de estas películas la trama consiste en un fastuoso montaje de la ópera de Bizet, en la segunda se trata de la documentación de los preparativos a lo largo de un sólo día de un programa para televisión, que se emitirá en directo esa misma noche, sobre los poetas andaluces, los de entonces y los de ahora. La voz en off del encargado de documentar la esperpéntica jornada, es decir, el director de la película que estamos viendo, alter ego del propio Martín Patino, nos va suministrando puntos de vista sobre la televisión y opiniones sobre lo que sucede a su alrededor. Invitados célebres y suplentes de los famosos, expertos a los que se enseña a hablar al ritmo que exige la televisión, locutores en su papel de estrellas mediáticas, el productor autoritario, los técnicos protestando, los figurantes, a los que se les dice cuándo tienen que aplaudir, insistiéndoles en que pongan "entusiasmo con los poetas, sobre todo con los poetas" (00:32:49), poetas muertos que van a ser representados por muñecos de cera para que los versos resulten más soportables, promotores que llegan con un cuadro de sevillanas y un toro de verdad como reclamo publicitario, testimonios reales... no falta nadie al espectáculo por excelencia de la España de los noventa, el espectáculo de los medios. Lo único que queda excluido es lo que se resiste a ser convertido en espectáculo, como ese investigador iluminado que afirma que Lorca no murió donde se cree, sino que estuvo viviendo tiempo después cerca de esa cartuja. "Demasiada imaginación para un profesor, ratón de bibliotecas. Tengo que defenderlo frente a los que lo quieren eliminar del programa por su falta de dotes para convertirlo en espectáculo" (00:13:5500:14:01). ¿Qué tendrá que ver todo esto con la poesía? parece preguntarse el realizador, mientras recuerda que él mismo escribió poemas cuando estaba en la universidad. Y por detrás de la poesía, una vez más, la historia de tantos siglos escrita sobre las ruinas de la cartuja desde donde se va a retransmitir el programa. "Rebeldía de ayer elevada a ortodoxia sacralizada" (00:34:17).

Mientras, suenan los versos de Rafael Alberti en la voz de Rosa León como leit-motiv de la película "¿Qué cantan los poetas, poetas andaluces, de ahora?" En ese ahora radica una vez más el conflicto y la posibilidad de la revelación, en el cruce entre lo que ha sido y lo que es. Despertar del mito (de la historia) por medio del propio mito amplificado, y reducido a burda representación en esta ocasión; des- 
pertar de la fascinación que produce la historia a través de la propia fascinación por las imágenes y el espectáculo teatral, que hablan de esa historia. El mundo dominado por sus fantasmagorias, dirá Baudelaire en una cita retomada en varias ocasiones por Benjamin $(2005,63)$, es la modernidad.

El diálogo con los mitos, con esa Andalucía emblemática que se pretendía exponer a través de estas películas documentales, no lleva sin embargo ni al homenaje ni a la apología. Recuperar estas construcciones de la tradición política o social, del flamenco o la cultura andaluza, en continuidad con el presente, es decir, como causa del momento actual, a modo de homenaje que se brinda desde hoy, lo que ese productor de televisión pretende hacer en el frustrado programa que debía de ser El jardín de los poetas, hubiera supuesto restablecer una línea de continuidad entre el pasado y el presente, que es justamente lo que se trata de evitar. En palabras de Benjamin $(2005,476)$ :

\begin{abstract}
El homenaje o la apología procuran encubrir los momentos revolucionarios del curso de la historia. Lo que de verdad les importa es establecer una continuidad. Valoran únicamente aquellos elementos de la obra que ha pasado a formar parte de su influjo. Se les escapan aquellos lugares donde la tradición se interrumpe, y con ella sus peñas y acantilados, que ofrecen un asidero a quien quiera ir más allá de ella.
\end{abstract}

Y la capacidad de romper esa continuidad que impide recuperar lo que aparentemente ha quedado fuera de la historia (de las imágenes) se sitúa, una vez más, en la carga de presente que puede llegar a tener esas imágenes. Esa impresión de proximidad es la que permite arrancar "violentamente la época de la sólida 'continuidad de la historia'. Pero también hace estallar la homogeneidad de la época. La carga con ecrasita, esto es, con presente" (Benjamin, 2005, 476).

La imagen que abre El jardín de los poetas, un rebaño de ovejas entre las ruinas de la cartuja donde se instalará el plató de televisión, puede resultar metafórica, o siguiendo a Benjamin incluso alegórica, y puede ser que hasta cómica. El locus amoenus enfrentado al mundo pragmático y material de la televisión, la paz de ese universo natural, que inspiró a poetas a lo largo de los siglos, transformado en actitud de resignación de las masas. Ante las quejas y sugerencias del equipo de colaboradores, el productor repite airado el discurso de autoridad que debe justificar cualquier arbitrariedad: "No estamos haciendo video-arte. Estamos haciendo televisión" (00:24:10), el medio convertido en estrategia de legitimación de sí mismo, un giro autorreferencial donde todo se justifica por su inclusión dentro del propio medio, que es también un mito, un medio de fascinación y mixtificación, transparente como todos los mitos cuando adquieren, al igual que los medios, su máxima eficacia. "La televisión va a ser definitivamente la historia. Pero inventándola de otra manera" (01:08:32), se dirá al final de la película mientras salen todos corriendo del plató, huyendo de un fuego -"repentino, inesperado, no sé si justiciero" (01:07:41)- provocado por un fallo técnico. La historia convertida en juego de artificios, mientras se oyen otra vez los versos de Alberti, "¿Qué cantan los poetas andaluces de ahora, qué miran los poetas andaluces de ahora...?".

Cada medio despliega un manto de seducción y también de mitificación. Para cada medio, como estudia Dubois (2001), se reorganiza un sistema de relaciones sobre el que se levanta un discurso, relaciones entre máquina y subjetividad, entre semejanza y desemejanza con lo representado o entre materialidad e inmaterialidad de la imagen. La televisión se proyecta desde una impresión de proximidad, de cercanía y casi intimidad. Simula una comunicación directa con el espectador, desde un aquí y ahora escénicos, y sin embargo creibles, y también la posibilidad de que él mismo, en cualquier momento, podría ser protagonista de esa historia que está viendo desde la intimidad de su casa, recostado en el sofá, poco antes de quedar dormido. Él mismo podría estar ahí opinando, discutiendo, dando su punto de vista, como un personaje más de los documentales de Martín Patino. Al igual que cualquier otro medio, la televisión trae un mundo de la mano, un mundo en este caso de comunicaciones cara a cara, en directo, que proyecta una sociedad imaginada construida entre todos de forma igualitaria a la vez que contribuye a la creación de un espacio individual, de proximidades y afectos. Ése es su mito y su sueño, también ahí radica su capacidad de seducción, en la identificación inmediata del que mira con lo que está mirando, sin trucos ni distancias. Por eso la tecnología digital, que ha hecho posible el mito de una televisión más "interactiva", ha sido asimilada con facilidad por este medio. Pero detrás de este ensueño de imágenes, sonrisas y emociones, se esconde la realidad material de un medio que está lejos de funcionar de manera democrática, 
está lejos de abrir los espacios necesarios para que el otro pueda hacerse sus propias opiniones, no impuestas, sobre lo que se le están diciendo antes que mostrando.

En El jardín de los poetas la exposición del medio remite directamente al funcionamiento de la propia televisión; en las otras películas de la serie no se habla explícitamente de la televisión, aunque de forma indirecta los comentarios implícitos sobre la materialidad de los medios remiten en última instancia a unos dispositivos de enunciación fácilmente reconocibles. La puesta en escena de la autenticidad televisiva no radica, sin embargo, en demostrar la verdad o la falsedad de unos determinados contenidos, ni tampoco en mostrar abiertamente la construcción técnica que sostiene el medio, sino en el juego de tensiones proyectado hacia el espectador entre una cosa y otra. La comunicación, aparentemente abierta e interactiva, en directo, que se le propone al espectador, es la piedra de toque de la impresión de autenticidad del medio televisivo. Ahora bien, esto puede ser manejado de maneras muy distintas. A menudo, la cuota de participación que se le da al espectador para que decida acerca de algo consiste más en una estrategia dirigida desde el propio medio para crear esta impresión de interactividad, de comunicación real. El efecto de realidad no radica en lo real de lo que se está mostrando, sino en la impresión de realidad que llega a tener esa comunicación en directo con el espectador. Finalmente, lo que se simula no es una representación de algo, ni siquiera la realidad material de un medio, para que parezca más verosímil, lo que se simula es la propia comunicación; ahí radica su efecto de realidad.

Sobre ese campo de interacción con el espectador se construyen la obra de Martín Patino y, más concretamente, estos documentales de la serie Andalucía. La diferencia es que ahora no se trata sólo de simular una comunicación directa con el espectador, utilizando los recursos caracteristicos del medio televisivo, puestos en juego a través de estas películas, sino que se arriesga en abrir un campo no predeterminado que sólo el espectador puede terminar cerrando. El sentido final de estas películas no está contenido en sí mismas, su mensaje último debe terminar de elaborarse fuera de la pantalla. Estos documentales, como toda la obra de Martín Patino, proponen más bien un juego, minuciosamente construido en cada ocasión, que el espectador debe aceptar, es el juego de la Historia, de lo objetivo y lo subjetivo, el juego de las verdades y las mentiras, de lo que es auténtico y es falso, un juego cuyo sentido último no puede ser impuesto desde fuera, sino que tiene que resolverse desde dentro de cada uno. Por detrás de este juego, como siempre, se deja ver el guiño cómplice del director, que parece decir mira a qué estoy jugando, un gesto a través del cual el propio director se distancia de su obra para dejarse ver, no ya como autor-idad, sino como alguien que construye artefactos, espectáculos con las imágenes, cara a cara con un espectador al que no se quiere ver reducido tampoco a un mero consumidor de imágenes. Por detrás de estas imágenes, construidas unas, rescatadas otras del pasado, por detrás de estos escenarios levantados con opiniones encontradas, con declaraciones de expertos y testigos que hablan frente a la cámara, en definitiva, por detrás de todos estos juegos, pareciera que lo último que se oye es una voz ahogada por una sonrisa socarrona que le dice al espectador idespierta! Es éste el momento en el que, como decía Benjamin (2005: 466), "la humanidad, frotándose los ojos, reconoce precisamente esta imagen onírica en cuanto tal. Es en este instante que el historiador [materialista] emprende con ella la tarea de la interpretación de los sueños" de toda una sociedad.

\section{NOTAS}

1 Puede consultarse una extensa bibliografía de y sobre Basilio Martín Patino, así como su filmografía completa en http://www.basiliomartinpatino.com.

\section{BIBLIOGRAFÍA}

Bellido López, Adolfo (1996): Basilio Martín Patino. Un soplo de libertad, Valencia, Filmoteca Generalitat Valenciana.

Benjamin, Walter (2005): Libro de los pasajes, Madrid, Akal.
Aceptado: 20 de marzo de 2009

doi: 10.3989/arbor.2011.748n2003

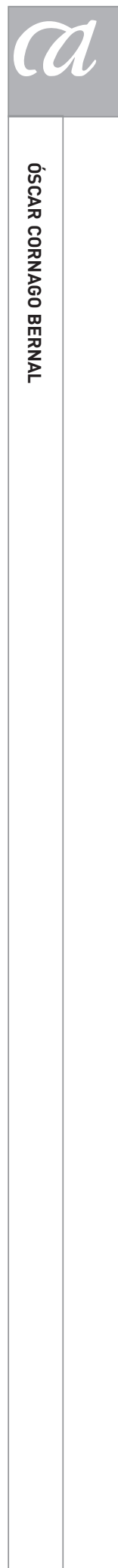


Breschand, Jean (2004): El documental. La otra cara del cine, Barcelona, Paidós.

Comolli, Jean-Louis (2007): Ver y poder. La inocencia perdida: cine, televisión, ficción, documental, Buenos Aires, Aurelia Rivera/Nueva Librería.

Cornago, Óscar (2005): Resistir en la era de los medios. Estrategias performativas en literatura, teatro, cine y televisión, Madrid/Frankfurt, Iberoamericana/Vervuert.

Cornago, Óscar y Lorena Verzero (2007): "Tentativas para una historia material (de los medios) en la II mitad del siglo XX", Comunicación. Revista Internacional de Comunicación Audiovisual, Publicidad y Estudios Culturales (Universidad de Sevilla), 5 (2007), pp. 67-92.

Dubois, Philippe (2001): Vídeo, cine, Godard, Buenos Aires, Libros del Rojas/ Universidad de Buenos Aires.
Frutos Esteban, Francisco Javier (1999): Artilugios para fascinar. Colección Basilio Martín Patino, Salamanca, Junta de Castilla-León/Ayuntamiento de Salamanca.

Martín, Carlos (coord.) (2008): En esto consistían los paraísos. Aproximación a Basilio Martín Patino, Granada, Diputación/Centro José Guerrero.

Martín Morán, Ana (2005): "La inocencia subversiva. Pistas falsas y alguna certeza sobre la producción de Basilio Martín Patino", en María Luisa Ortega (coord.), pp. 47-82.

Martín Patino, Basilio (1987): "Filmar Madrid" (http://www.basiliomartinpatino.com/escritos.htm).

Martín Patino, Basilio y Ana Useros (2004): "Basilio Martín Patino. Del No-Do al mercado del cine", $L a$ Dinamo, 9 (2004) (www.ladinamo. org).
Nieto Ferrando, Jorge (2006): Posibilismos, memorias y fraudes. El cine de Basilio Martín Patino, Valencia, Ediciones de la Filmoteca.

Ortega, María Luisa (coord.) (2005): Nada es lo que parece. Falsos documentales, hibridaciones y mestizajes del documental en España, Madrid, Ocho y Medio/Ayuntamiento de Madrid.

Pérez Millán, Juan Antonio (2002): La memoria de los sentimientos. Basilio Martín Patino y su obra audiovisual, Valladolid, Semana Internacional de Cine de Valladolid/Sociedad General de Autores y Editores.

Torreiro, Casimiro y Josetxo Cerdán (eds.) (2005): Documental y vanguardia, Madrid, Cátedra, 2005.

Weinrichter, Antonio (2005): "Jugando en los archivos de lo real. Apropiación y remontaje en el cine de no ficción", en Casimiro Torreiro y Josetxo Cerdán (eds.), 2005, pp. 43-64. 